\title{
Cigarette smoke condensate-induced oxidative DNA damage and its removal in human cervical cancer cells
}

\author{
AFSOON MOKTAR ${ }^{1,2}$, RAJESH SINGH ${ }^{2,4}$, MANICKA V. VADHANAM ${ }^{2}$, SRIVANI RAVOORI $^{2}$, \\ JAMES W. LILLARD ${ }^{2,4}$, C. GARY GAIROLA ${ }^{3}$ and RAMESH C. GUPTA ${ }^{1,2}$ \\ ${ }^{1}$ Department of Pharmacology and Toxicology, ${ }^{2}$ James Graham Brown Cancer Center, University of Louisville, \\ Louisville, KY; ${ }^{3}$ Graduate Center of Toxicology, University of Kentucky, Lexington, KY, USA
}

Received April 7, 2011; Accepted May 23, 2011

DOI: $10.3892 /$ ijo.2011.1106

\begin{abstract}
Exposure to cigarette smoke is well documented to increase oxidative stress and could account for higher risk of cervical cancer in smokers. Cervical pre-cancerous lesions that are initiated by human papillomavirus (HPV) infection generally regress in the absence of known risk factors such as smoking. 8-oxodeoxyguanosine (8-oxodG) is a highly mutagenic oxidative DNA lesion that is formed by the oxidation of deoxyguanosine. In the present study, we examined: a) the effect of cigarette smoke condensate (CSC) on 8-oxodG formation in and its removal from HPV-transfected (ECT1/E6 E7), HPV-positive (CaSki) and HPV-negative (C33A) human cervical cancer cells, and b) the cell cycle progression and apoptosis in CSC-treated ECT1/E6 E7 cells. CSC induced 8-oxodG in a dose- $(\mathrm{p}=0.03)$ and time $(\mathrm{p}=0.002)$-dependent fashion in ECT1/E6 E7 cells as determined by flow cytometry. A 2.4-fold higher level of 8-oxodG was observed in HPV-positive compared with HPV-negative cells. However, 8-oxodG lesions were almost completely removed $72 \mathrm{~h}$ post-exposure in all cell lines as determined by ImageStream analysis. This observation correlates with the 2- and 5-fold increase in the p53 levels in ECT1/E6 E7 and CaSki cells with no significant change in C33A cells. We conclude that: a) cigarette smoke constituents induce oxidative stress with higher burden in HPV-positive cervical cancer cells and $b$ ) the significant increase observed in p53 levels in wild-type cervical cells (ECT1/E6 E7 and CaSki) may be attributed to the $\mathrm{p} 53$-dependent DNA repair pathway while a p53-independent pathway in C33A cells cannot be ruled out.
\end{abstract}

Correspondence to: Dr Ramesh Gupta, University of Louisville, 304E Delia Baxter II, 580 S. Preston Street, Louisville, KY 40202, USA

E-mail: rcgupta@louisville.edu

Present address: ${ }^{4}$ Department of Microbiology, Biochemistry and Immunology, Morehouse School of Medicine, Hugh Gloster Building, 720 Westview Drive, Atlanta, GA 30310, USA

Key words: cigarette smoke condensate, human cervical cancer cells, HPV, oxidative DNA damage, DNA repair

\section{Introduction}

A role of cigarette smoking as a causative factor in the development of cervical cancer was proposed by Winkelstein (1). Considering the fact that the cause of cervical cancer is multifactorial and HPV infection alone is not sufficient but necessary in its etiology, the interaction of HPV and cigarette smoke has been proposed (2-4). The effects of cigarette smoke as a heterogeneous component on the extent of oxidative DNA damage in cells are 2-fold. First, the tar and gas-phase of smoke are rich sources of free radicals, such as the quinonehydroquinone-semiquinone system and nitric oxide (5), which can induce different oxidative DNA lesions, such as 8-oxo7,8-dihydro-2'-deoxyguanosine (8-oxodG) (6). Second, the involvement of cigarette smoke free radicals in carcinogenesis has been well documented and reviewed elsewhere (7-9). The levels of oxidative base lesions were reported higher in smokers as compared to non-smokers (10-12).

Insight into the mechanisms by which DNA of high-risk HPV transforms cervical cells arose from the realization that the virus oncoproteins interact with specific cell regulatory proteins. The E6 oncoprotein causes degradation of the cellular protein 553 by the ubiquitin-proteasome pathway; the E7 oncoprotein interacts with the retinoblastoma protein and inactivates it (13). The tumor suppressor $\mathrm{p} 53$ primarily functions as a transcription factor, but several responses can be generated by $\mathrm{p} 53$, including cell cycle arrest or apoptosis (14). The status of p53 in cervical cancer has previously been investigated. It appears that the inactivation of the normal function of p53 is a critical step in human cervical carcinogenesis, which can be either caused by mutation, as in HPV-negative cells (15), or from complex formation with E6 oncoproteins in case of HPV-positive cervical cancer cells (16).

HPV-positive cervical cancer cells have been shown to possess residual p53 activity indicating that p53 is not completely inactivated by binding to E6 oncoprotein (17-19). These findings might indicate the possibility of p53 involvement in HPV-positive cell response in removing the oxidative DNA damage. There is evidence that $\mathrm{p} 53$ has a more positive role in facilitating the repair of oxidative lesion by its involvement in base excision repair (BER), a DNA repair pathway (20). However, the existence of p53-independent repair pathway should also be considered since cells devoid of HPV sequence 
did not show a p53-mediated response to oxidative DNA damage (21).

This work was designed to investigate: a) the effect of CSC on 8-oxodG formation in and its removal from HPV-transfected (ECT1/E6 E7), HPV-positive (CaSki) and HPV-negative (C33A) human cervical cancer cells, and b) the cell cycle progression and apoptosis in the CSC-treated ECT1/E6 E7 cells. The transfected cell line was chosen as a standardized in vitro model (22) to further understand the interplay of cigarette smoke-free radicals and cervical carcinogenesis.

\section{Materials and methods}

Cell lines and cell culture. HPV-16 transformed human ectocervical cells, ECT1/E6 E7, were a generous donation by Dr Raina Fichorova, Brigham and Women's Hospital, Harvard Medical School. HPV-16 positive human cervical cells, CaSki, and HPV-negative human cervical cells, C33A, were purchased from ATCC (Manassas, VA). ECT1/E6 E7 cells were cultured as monolayer in K-SFM supplemented with $0.3 \%$ BPE, $0.1 \mathrm{ng} / \mathrm{ml} \mathrm{EGF}, 0.4 \mathrm{mM} \mathrm{CaCl} 2,1 \%$ penicillin and streptomycin at $37^{\circ} \mathrm{C}$ and $5 \% \mathrm{CO}_{2}$. CaSki and $\mathrm{C} 33 \mathrm{~A}$ cells were routinely cultured in RPMI-1640 media supplemented with $5 \%$ fetal bovine serum (FBS) in a humidified atmosphere of $5 \% \mathrm{CO}_{2}$ at $37^{\circ} \mathrm{C}$. All the cell lines were seeded at a density of approximately 6,000 cells $/ \mathrm{cm}^{2}$ in $25 \mathrm{~cm}^{2}$ cell culture flasks. All the cell lines were authenticated by DNA (STR) profiling at the Core Fragment Analysis Facility at Johns Hopkins University on March 15, 2010.

Preparation of CSC. University of Kentucky research cigarettes $(2 \mathrm{R} 4 \mathrm{~F})$ were smoked in a Borgwardt 30-port smoking machine under standard FTC protocol (23). The particulates were collected on Cambridge filters and were dissolved in DMSO to obtain a $4 \%$ solution. The stock CSC solutions were stored in small aliquots at $-80^{\circ} \mathrm{C}$. A fresh vial was used for each experiment.

8-oxodG formation. CSC treatment of the cells was carried out as described elsewhere (24). Briefly, after cells reached 60-70\% confluence, they were treated with either $0.2 \% \mathrm{v} / \mathrm{v}$ DMSO or with 4,8 and $12 \mu \mathrm{g} / \mathrm{ml} \mathrm{CSC}$ in DMSO for up to $72 \mathrm{~h}$ in order to induce the maximum oxidative DNA damage and then harvested by Trypsin/EDTA solution. The cells were kept on ice at all times to minimize DNA repair. 8-oxodG formation was measured by flow cytometry.

DNA repair. The cells were treated with 4,8 or $12 \mu \mathrm{g} / \mathrm{ml} \mathrm{CSC}$ for $72 \mathrm{~h}$. Residual CSC was removed by washing the cells three times with $5 \mathrm{ml}$ medium, followed by incubation of the cells with the fresh medium for an additional 24,48 , or $72 \mathrm{~h}$ at $37^{\circ} \mathrm{C}$ to allow repair of oxidative DNA damage to occur. Subsequently, 8-oxodG levels were measured by flow cytometry.

Flow cytometry and ImageStream analysis of 8-oxodG and $p 53$ expressions. Primary polyclonal goat anti-8-OHdG antibody was purchased from Chemicon International; and primary polyclonal goat anti-p53 antibody was purchased from Santa Cruz Biotechnology. Briefly, all cell lines were harvested and fixed in $70 \%$ ethanol and stored at $-20^{\circ} \mathrm{C}$ for later processing. Upon thawing, cells were washed one time in phosphate-buffered saline (PBS) followed by another wash with FACS buffer (1\% BSA in PBS). Next, cells were permeabilized with $0.1 \%$ Triton X-100 for $20 \mathrm{~min}$ on ice at room temperature (RT), followed by washing with PBS. For 8-oxodG staining, primary antibody (1-3 mg/ml) was incubated with Zenon Fab-Alexa Fluor 488 goat IgG labeling reagent $(5 \mu \mathrm{l})$ (Invitrogen, Carlsbad, CA), and cells were stained for $30 \mathrm{~min}$ at room temperature in dark. Alternatively, to stain for p53, fixed, washed and permeabilized cells were stained with $1 \mu \mathrm{g}$ p53 primary antibody labeled with $5 \mu \mathrm{l}$ of the Zenon Fab-Alexa Fluor 488 goat IgG labeling reagent for $30 \mathrm{~min}$ at room temperature in dark. Cells were washed with FACS buffer. For nuclear staining, $10^{6}$ cells were incubated with $0.25 \mu \mathrm{g}$ of 7-amino-actinomycin $\mathrm{D}$ (7AAD; BD-PharMingen) resuspended in FACS buffer and analyzed within $30 \mathrm{~min}$. Around $5 \times 10^{4}$ cells were analyzed by flow cytometry using a FACSCalibur flow cytometry and CellQuest ${ }^{\mathrm{TM}}$ software (BectonDickinson, San Jose, CA, USA) to assess cell cycle, apoptosis and p53 expression. Expression of p53 was defined in terms of total fluorescent intensity, which was calculated by multiplying number of cell events by mean intensity. Correspondingly, $10^{4}$ stained cells were analyzed using an ImageStream System and IDEAS 3.0 software (Amnis) to assess 8-oxodG expression. 8-oxodG total fluorescent intensity was calculated by multiplying the cell events by mean fluorescent intensity.

Cell cycle analysis. Cell cycle phase distribution of ECT1/E6 E7 cells was analyzed by flow cytometry (BD Biosciences, San Jose, CA). CSC-treated cells and appropriate controls $\left(2 \times 10^{5}\right)$ were collected after $24 \mathrm{~h}$, washed twice with PBS and fixed with ice-cold $70 \%$ ethanol at $4^{\circ} \mathrm{C}$ for $30 \mathrm{~min}$ to $1 \mathrm{~h}$. The cells were then treated with $10 \mu \mathrm{g} / \mathrm{ml}$ propidium iodide (PI, SigmaAldrich, St. Louis, MO), $2.5 \mu \mathrm{g} / \mathrm{ml}$ RNase A (Sigma-Aldrich) and $0.1 \%$ Triton X-100 in dark at $37^{\circ} \mathrm{C}$ for $30 \mathrm{~min}$. Data were collected, stored and analyzed using FlowJo software (BectonDickinson).

Apoptosis detection. Apoptosis in ECT1/E6 E7 cells was detected using an Alexa Fluor ${ }^{\circledR} 488$ Annexin V/propidium iodide kit (Invitrogen), according to the manufacturer's instructions. Briefly, $1 \times 10^{6}$ cells were treated with vehicle or 4 , $8,12 \mu \mathrm{g} / \mathrm{ml} \mathrm{CSC}$ for $24 \mathrm{~h}$. After harvesting, cells were washed with cold PBS, and then stained with $5 \mu$ l Annexin V-FITC and $0.1 \mu \mathrm{g} / \mathrm{ml}$ propodium iodide (PI) for each $100 \mu \mathrm{l}$ of cell suspension and incubated at room temperature for $15 \mathrm{~min}$. The apoptotic cells were determined using FACSCalibur flow cytometry (Becton-Dickinson). Data analysis was performed using FlowJo software. It is important to note that a quadrant quantification method could not be used in apoptotic cell determination, since CSC treatment affected the cell distribution using that method. Therefore, both early apoptotic (Annexin V-positive and PI-negative) and late apoptotic (Annexin V-positive and PI-positive) cells were considered in the cell death determination.

Statistical analysis. The total fluorescent intensity levels are expressed as the mean \pm SD (standard deviation) and analyzed for statistical significance $(\mathrm{p}<0.05)$ using Student's t-test. Statistical analysis of dose response was calculated using One-way analysis of variance (ANOVA). 

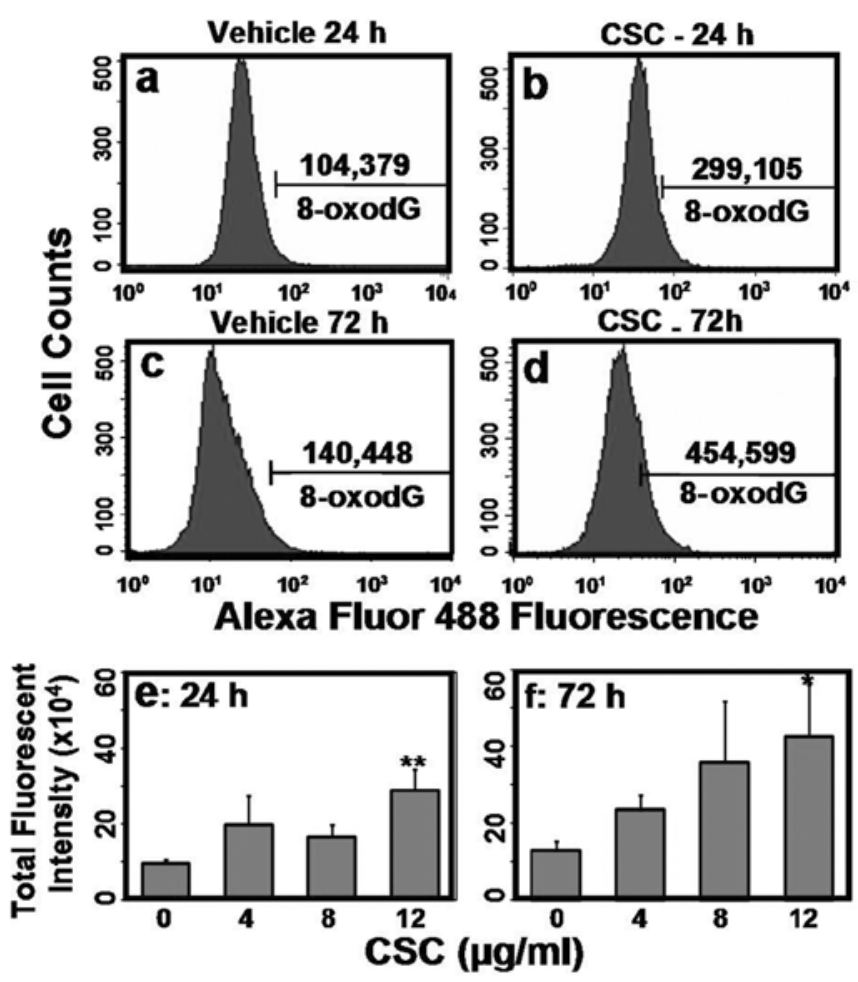

Figure 1. CSC-induced 8-oxodG lesion in ECT1/E6 E7. Cells treated with vehicle for 24 (a) and $72 \mathrm{~h}$ (c) and CSC (12 $\mu \mathrm{g} / \mathrm{ml})$ for $24 \mathrm{~h}$ (b) and $72 \mathrm{~h}$ (d) were stained with Alexa Flour 488-conjugated anti-8-OHdG and quantified by flow cytometry. (e and f) represent dose- and time-response to CSC-induced oxidative DNA damage as measured by 8 -oxodG total fluorescent intensity.
Results

8-oxodG formation in HPV-transfected cervical cells. A significant increase (3-fold; $\mathrm{p}=0.004$ ) in 8-oxodG level was detected following treatment of cells with $12 \mu \mathrm{g} / \mathrm{ml} \mathrm{CSC}$ for $24 \mathrm{~h}$ compared with vehicle treatment (Fig. la and b); the 8-oxodG levels were further increased (3-fold; $p=0.01$ ) after $72 \mathrm{~h}$ (Fig. 1c and $d)$. Formation of 8-oxodG lesion was both dose- $(p=0.01)$ and time $(\mathrm{p}=0.002)$-dependent (Fig. 1e and $\mathrm{f})$.

8-oxodG removal in cervical cells. To examine the ability of cervical cells to remove CSC-induced oxidative DNA damage, we investigated the residual 8-oxodG total fluorescent intensity for different periods of recovery time. The highest level of oxidative DNA damage measured as total fluorescent intensity $\mathrm{x} 10^{5}$ was found to be in ECT1/E6 E7 cells (104 \pm 19$)$, followed by CaSki $(2.7 \pm 0.71)$ and C33A $(0.66 \pm 0.083)$ cells.

ECT1/E6 E7 and C33A cells showed a 3-fold $(\mathrm{p}=0.007)$ and 2 -fold $(\mathrm{p}=0.02)$ increase in 8 -oxodG level in the first $24 \mathrm{~h}$, respectively [Fig. 2a and c (iv)]. In contrast, a 3-fold $(\mathrm{p}=0.07)$ decrease in oxidative damage was observed in CaSki cells in the first $24 \mathrm{~h}$ [Fig. 2b (iv)]. However, 8-oxodG lesion was essentially removed from all the cell lines by $72 \mathrm{~h}$ (Fig. 2).

p53 assessment in cervical cells. The different cervical cells treated with vehicle or CSC during the repair phase of 8-oxodG were also analyzed for p53 levels in order to elucidate its involvement in cell cycle phase distribution, apoptosis induction, and removal of oxidative DNA lesion. As quantified

\section{a. HPV-transfected cells}

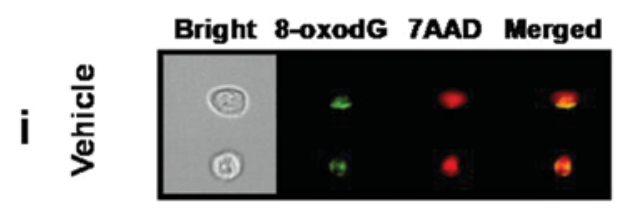

$$
\text { ii }
$$
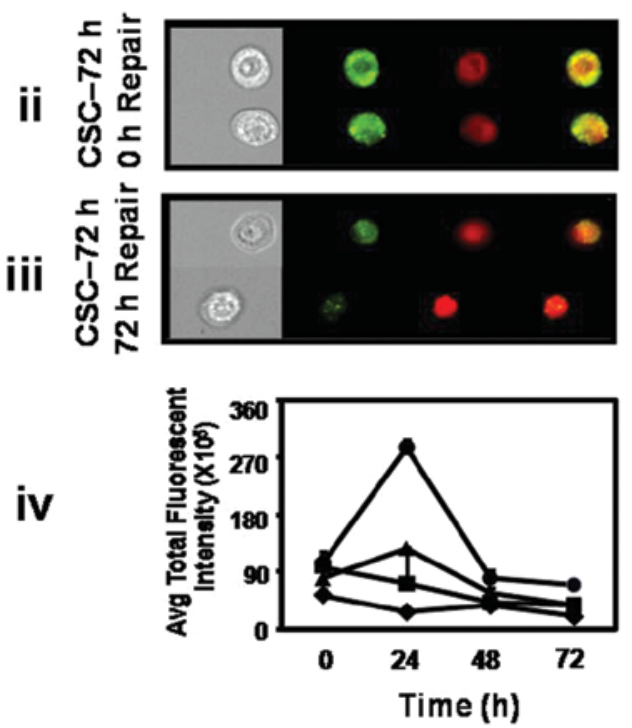

b. CaSki Cells

Bright 8-oxodG 7AAD Merged
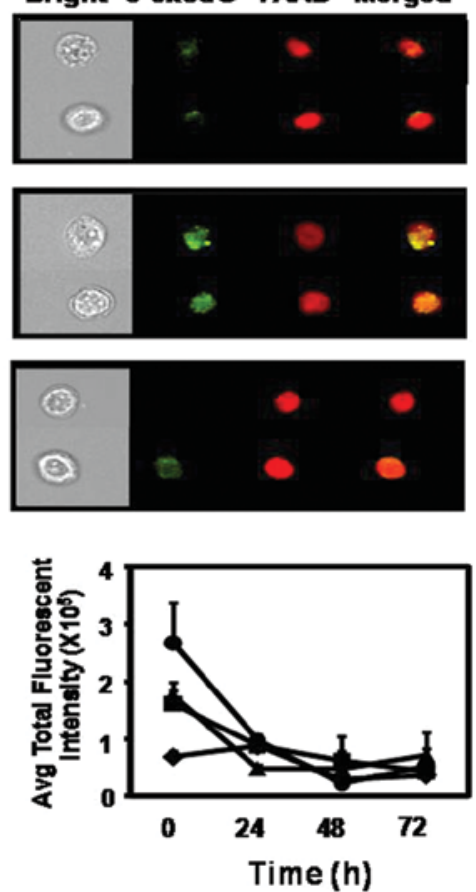

c. C33A Cells
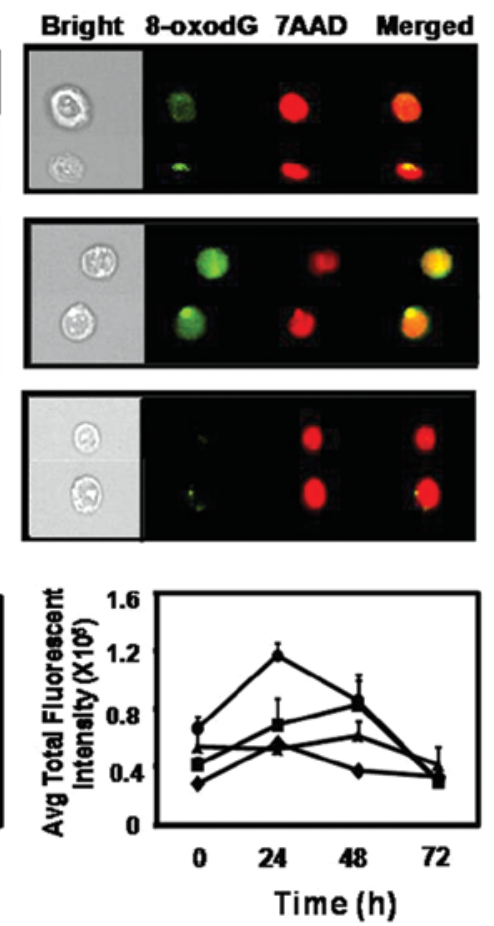

Figure 2. Removal of CSC-induced oxidative DNA damage in ECT1/E6 E7 (a), CaSki (b), and C33A (c) cells: cells treated with vehicle (i) and CSC (12 $\mu$ g/ ml) (ii) for $72 \mathrm{~h}$, and $72 \mathrm{~h}$ post-CSC exposure (iii) were stained with Alexa Flour 488-conjugated anti-8-OHdG, and the images were acquired by multispectral imaging flow cytometry. (iv) denotes kinetics of removal of CSC-induced oxidative DNA damage: $\mathrm{rhombus}(0 \mu \mathrm{g} / \mathrm{ml}), \mathrm{square}(4 \mu \mathrm{g} / \mathrm{ml})$, triangle $(8 \mu \mathrm{g} / \mathrm{ml})$, and circle $(12 \mu \mathrm{g} / \mathrm{ml}) \mathrm{CSC}$. 


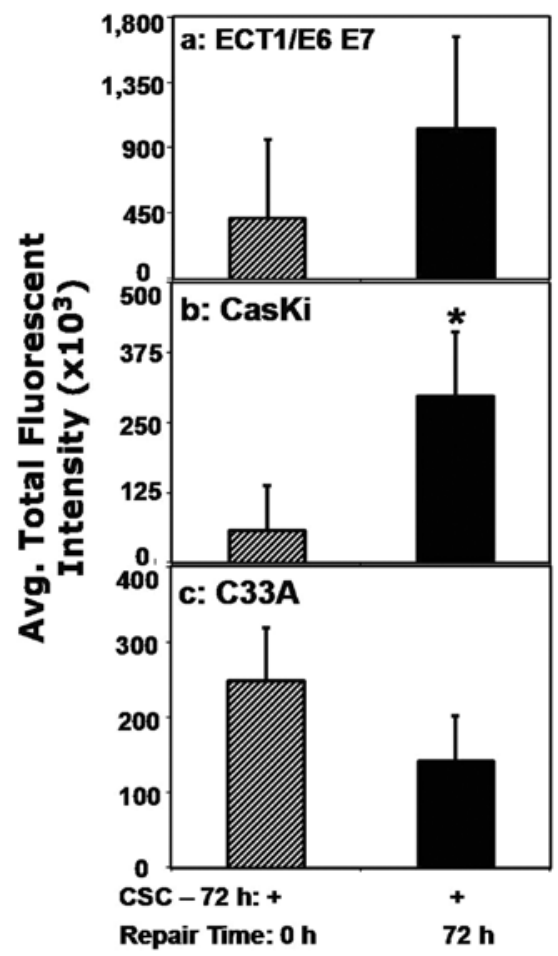

Figure 3. Assessment of $\mathrm{p} 53$ expression in different human cervical cells. ECT1/ E6 E7 (a), CaSki (b), and C33A (c) cells were treated with CSC (12 $\mu \mathrm{g} / \mathrm{ml})$ for $72 \mathrm{~h}$ to induce the 8-oxodG lesion. Then, cells were freed of the residual CSC and further incubated for $72 \mathrm{~h}$ for repair of oxidative DNA damage to occur, stained with Alexa Flour 488-conjugated anti-p53 antibody and quantified by flow cytometry. by flow cytometry, p53 total fluorescent intensity was increased by 2 - and 5-fold in ECT1/E6 E7 (Fig. 3a) and CaSki cells (Fig. 3b), respectively, but it was diminished by 1.7 -fold in $\mathrm{C} 33 \mathrm{~A}$ cells (Fig. 3c).

Cell cycle phase distribution in HPV-transfected cervical cells. p53 is non-functional in cervical cells harboring HPV infections due to the co-expression of the E6 oncoprotein. Therefore, a CSC-induced cell cycle arrest is not expected in these cells. To test this, we investigated the cell cycle changes in immortalized cervical cells after CSC exposure for $24 \mathrm{~h}$. Nearly one half $(46.6 \%)$ of vehicle-treated cells were at $\mathrm{G}_{1}$-phase, $24.9 \%$ in S-phase and $28.3 \%$ in $\mathrm{G}_{2}$-phase. After treatment with CSC (12 $\mu \mathrm{g} / \mathrm{ml})$, the $\mathrm{G}_{1}$-phase cells increased to $60.3 \%$ while the proportion of S-phase decreased to $17.4 \%$. However, there was no significant change in percentage of cells in $\mathrm{G}_{2}$-phase postCSC exposure (Fig. 4). These data suggest that CSC treatment resulted in $\mathrm{G}_{0} / \mathrm{G}_{1}$-phase arrest.

Apoptosis induction in HPV-transfected cervical cells. We examined the percentage of cells going through apoptosis as a possible mechanism by which CSC affects cells. CSC treatment induced apoptosis, as evidenced by a dose-dependent increase in the percentage of apoptotic cells at 24-h treatment in ECT1/ E6 E7 cells: $9.7 \%$ of vehicle-treated cells were apoptotic which increased to $11.5 \%, 16.6 \%$, and $26.6 \%$ after treatment with 4,8 , $12 \mu \mathrm{g} / \mathrm{ml}$ CSC treatment, respectively. Fig. 5 depicts the effect at the highest concentration tested.
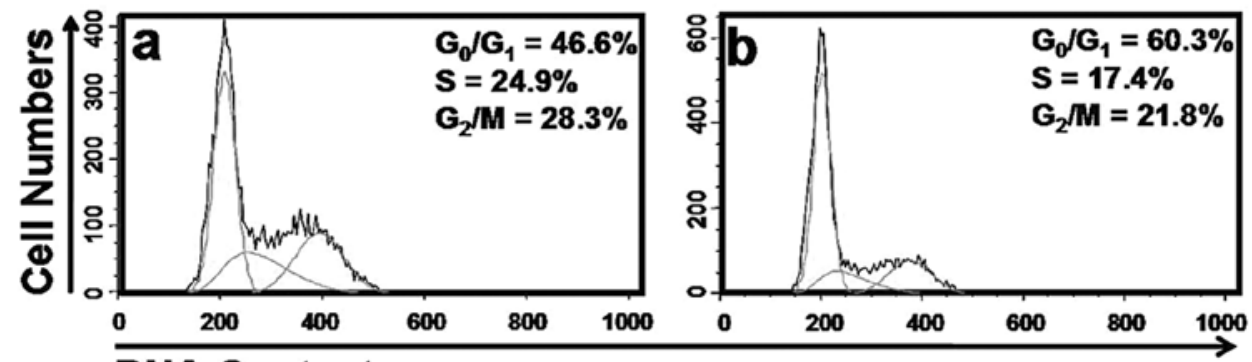

DNA Content

Figure 4. Effects of CSC on cell cycle distribution in HPV-transfected cervical cells. Flow cytometry analysis using propidium iodide staining to determine cell cycle phase distribution following vehicle (a), and CSC (12 $\mu \mathrm{g} / \mathrm{ml})(\mathrm{b})$ treatment for $24 \mathrm{~h}$.
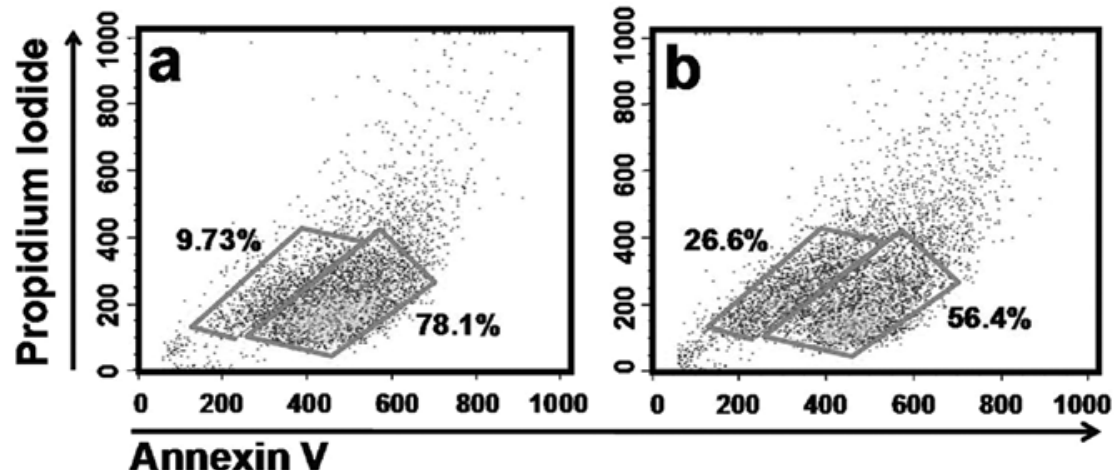

Figure 5. CSC-induced apoptosis in HPV-transfected cells. Apoptosis was induced with 0 (a) and $12 \mu \mathrm{g} / \mathrm{ml} \mathrm{CSC}$ (b) for $24 \mathrm{~h}$ and cells were stained with Annexin V-FITC and quantified by flow cytometry. 


\section{Discussion}

We previously showed that CSC can induce both dose- and time-dependent single- and double-strand breaks in cervical cells (24). In the present study, we show that CSC induces 8-oxodG lesion in a dose- and time-dependent fashion in the HPV-transfected cervical cell line, ECT1/E6 E7. It is well documented that cigarette smoke or its components induce oxidative DNA damage (25), which is believed to be highly mutagenic and carcinogenic (26). In the present study, the highest levels of oxidative DNA damage was observed by treatment of cervical cells with $12 \mu \mathrm{g} / \mathrm{ml} \mathrm{CSC}$ for $72 \mathrm{~h}$. This highlights the inherent vulnerability of cervical cancer cells to CSC-induced oxidative stress; a dose- and time-related increase in 8-oxodG lesion in cervical cells emphasizes the important role of the CSC-induced oxidative DNA damage in cervical carcinogenesis. Our finding supports epidemiological and experimental data suggesting that cigarette smoke induces oxidative stress.

Furthermore, our data showed that there is a difference in the extent of DNA damage between HPV-transfected and positive cell lines. We observed that ECT1/E6 E7 cells showed a much higher level of CSC-induced oxidative damage compared to CaSki cells. One possible explanation is that the immortalized cells may be more prone to oxidative injury. This is in agreement with the study of Wilmer and coworkers who showed that cystinotic cell lines immortalized with HPV E6/E7 appear to show increased oxidative stress and altered redox status compared to control cells (27). C33A cells showed the lowest level of 8-oxodG in response to CSC compared with ECT1/E6 E7 and CaSki cells. This observation might be due to the lack of synergistic impact of HPV on CSC-induced oxidative DNA damage in C33A cells, which are devoid of HPV sequences. This contrasts with the studies of Wei et al that showed the DNA damage and mutation were decreased in cells harboring high-risk HPV infection in response to nitric oxide, a source of oxidative damage resulting from cigarette smoking (28). Nonetheless, we speculate that carcinogenic HPV induces a higher burden of oxidative DNA damage in cervical cells, which may directly point to the critical role of HPV in CSCinduced oxidative injury.

Oxidative DNA damage has been shown to trigger activation of several cellular processes, such as apoptosis and cell cycle checkpoint, in order to maintain cellular homeostasis (29). The current study demonstrates that in addition to increasing 8-oxodG lesion levels in cervical cells, CSC can induce a dosedependent increase in apoptosis in ECT1/E6 E7 cells with an arrest at $\mathrm{G}_{0} / \mathrm{G}_{1}$-phase of cell cycle. However, CSC-induced apoptosis occurred in small percentages of cells. The remaining surviving cells may undergo proliferation, which, in turn, compromises the genomic integrity of the cells by increasing the possibilities of accumulation of DNA mutations. Similar observation was reported by Liu et al on the effect of cigarette smoke extract on human bronchial epithelial cells (30). The fact that almost $50 \%$ of cells resist the cell cycle arrest as shown in this study may also play a role in genomic instability; these cells have altered function, which may eventually contribute to cervical pathogenesis. These results also suggest that DNA repair processes can be initiated in response to DNA damage by cigarette smoke since many cells undergo oxidative DNA damage, apoptotic activation pathway and cell cycle checkpoint but survive; these cells may harbor genomic instability.

Intriguingly, 8-oxodG removal was most efficient (93\%) in HPV-positive CaSki cells compared to HPV-negative C33A, which did not reveal any significant removal of the oxidative DNA damage up to $48 \mathrm{~h}$. Different scenarios could be considered to explain the differences in the responses of HPV-positive and negative cell lines to CSC-induced oxidative DNA damage in the present study. One possibility may be due to the residual activity of p53 that has been reported in cervical cancer cells $(18,19)$; CaSki cells have the highest basal p53 activity (17). Our data support these findings that basal p53 activity exists in CaSki cells, and to some extent in ECT1/E6 E7 cells, despite the co-expression of the viral E6 oncogene. However, C33A, containing mutant p53 genes lacked the p53-mediated response to DNA damage (18). In concordance with the notion that the p53 protein is functional in HPV-infected cells, we observed that oxidative DNA damage was removed most efficiently in the following order: CaSki > ECT1/E6 E7 > C33A. These findings suggest that the presence of residual p53 activity in HPV-infected cells may have a role in removal of oxidative DNA damage.

Our data clearly showed that expression of p53 differed between HPV-positive and negative cervical cells in response to CSC-induced DNA damage. The data revealed that $\mathrm{p} 53$ expression was not altered in C33A. In contrast, in HPV-positive cells, p53 expression was higher during the removal phase of the oxidative DNA damage. These findings are congruent with the results of several studies indicating the existence of residual wild-type p53 activity in cervical carcinoma cells $(18,19)$. The authors showed HPV-positive cancer cells contained enough p53 to elucidate the activity of a downstream p53 upon exposure to genotoxic stress. On the other hand, Kessis et al (31) showed that DNA damage could not stimulate p53-dependent activities in HPV-16 E6-expressing cells. This finding was due primarily to an augmented E6 response generated by constitutive promoters. The observation that the HPV-negative cells could achieve the same level of DNA repair after $72 \mathrm{~h}$ post-exposure along with their unaltered p53 expression may thus provide possible evidence for the existence of the p53-independent repair pathway (21). This is due to the inactivation of $\mathrm{p} 53$ by the mutation of the gene in these cells $(32,33)$. The precise mechanistic pathway responsible for the delayed repair in C33A and HPV-transfected cells as compared to HPV-positive cells requires further investigation.

The notion that $\mathrm{p} 53$ plays a role in BER is supported by the observation that the cell extracts expressing wild-type p53 exhibit an enhanced BER response, which was later abolished upon p53 depletion (20). Further, a study by Zhou et al has suggested that p53 is directly involved in BER, which might be due to its dual functions: as a responder of DNA damage and also as an active participant in repairing the induced damage (34). These studies directly support our findings that p53 may have played an integral role in removal of the CSC-induced oxidative damage in the cells expressing wild-type p53 despite the co-expression of the E6 oncogene.

It is of interest to note that oxidative DNA damage was sharply increased in the first $24 \mathrm{~h}$ after withdrawal of CSC in 
HPV-transfected and negative cells. A similar observation of a transient increase of oxidative DNA damage following cessation of smoke exposure in the lung of $\mathrm{A} / \mathrm{J}$ mice has been made (35). This finding could be explained by the heterogeneous nature of CSC, including carcinogens, promoters, tumor inhibitors, and DNA repair inhibitors $(36,37)$. Thus, the transient increase in oxidative DNA damage detected in our studies could possibly be due to the effect of DNA repair inhibitors in conjunction with free radical-producing quinones/semiquiniones in CSC.

To conclude, we have demonstrated that CSC-induced oxidative DNA damage is more pronounced in HPV-infected cells. We also have shown that 8 -oxodG was removed almost completely $72 \mathrm{~h}$ post-exposure in all the cervical cell lines tested, regardless of HPV status. The similarity of responses to CSC-induced oxidative DNA damage between cell lines expressing mutant p53 or the E6 oncoprotein suggests that interaction of E6 and p53 may be functionally comparable to $\mathrm{p} 53$ mutations. These observations lead us to presume the possibility of both p53-dependent and independent DNA repair pathways in our experimental setting. Though CSC-induced oxidative DNA damage was eventually removed in all the cells, the possibility of error-prone DNA repair, however, cannot be ruled out. Chakravarti et al have shown that $\mathrm{DB}[a, l] \mathrm{P}$-induced DNA depurinating lesions are subject to error-prone excision repair in pre-S-phase cells, which generates heteroduplex mutations in the $\mathrm{H}-$ ras gene (38). The error-prone DNA repair may render cells susceptible to the accumulation of genetic mutations associated with carcinogenesis and tumor progression.

\section{Acknowledgments}

This work was supported from Agnes Brown Duggan Endowment and, in part, USPHS training grant ES-011564.

\section{References}

1. Winkelstein W Jr: Smoking and cancer of the uterine cervix: hypothesis. Am J Epidemiol 106: 257-259, 1977.

2. Haverkos H, Rohrer M and Pickworth W: The cause of invasive cervical cancer could be multifactorial. Biomed Pharmacother 54: 54-59, 2000

3. Castle PE, Wacholder S, Lorincz AT, et al: A prospective study of high-grade cervical neoplasia risk among human papillomavirus-infected women. J Natl Cancer Inst 94: 1406-1414, 2002.

4. Haverkos HW, Soon G, Steckley SL and Pickworth W: Cigarette smoking and cervical cancer: Part I: a meta-analysis. Biomed Pharmacother 57: 67-77, 2003.

5. Pryor WA, Prier DG and Church DF: Electron-spin resonance study of mainstream and sidestream cigarette smoke: nature of the free radicals in gas-phase smoke and in cigarette tar. Environ Health Perspect 47: 345-355, 1983.

6. Park EM, Park YM and Gwak YS: Oxidative damage in tissues of rats exposed to cigarette smoke. Free Radic Biol Med 25: 79-86, 1998.

7. Copeland ES: A National Institutes of Health Workshop report. Free radicals in promotion - a chemical pathology study section workshop. Cancer Res 43: 5631-5637, 1983.

8. Valavanidis A, Vlachogianni T and Fiotakis K: Tobacco smoke: involvement of reactive oxygen species and stable free radicals in mechanisms of oxidative damage, carcinogenesis and synergistic effects with other respirable particles. Int J Environ Res Public Health 6: 445-462, 2009.

9. Mena S, Ortega A and Estrela JM: Oxidative stress in environmental-induced carcinogenesis. Mutat Res 674: 36-44, 2009.
10. Kiyosawa $\mathrm{H}$, Suko M, Okudaira $\mathrm{H}$, et al: Cigarette smoking induces formation of 8-hydroxydeoxyguanosine, one of the oxidative DNA damages in human peripheral leukocytes. Free Radic Res Commun 11: 23-27, 1990.

11. Loft S, Vistisen K, Ewertz M, Tjonneland A, Overvad K and Poulsen HE: Oxidative DNA damage estimated by 8-hydroxydeoxyguanosine excretion in humans: influence of smoking, gender and body mass index. Carcinogenesis 13: 2241-2247, 1992.

12. Asami S, Hirano T, Yamaguchi R, Tomioka Y, Itoh $\mathrm{H}$ and Kasai H: Increase of a type of oxidative DNA damage, 8-hydroxyguanine, and its repair activity in human leukocytes by cigarette smoking. Cancer Res 56: 2546-2549, 1996.

13. Bosch FX, Rohan T, Schneider A, et al: Papillomavirus research update: highlights of the Barcelona HPV 2000 International Papillomavirus Conference. J Clin Pathol 54: 163-175, 2001.

14. Vousden KH and Lu X: Live or let die: the cell's response to p53. Nat Rev Cancer 2: 594-604, 2002.

15. Scheffner M, Munger K, Byrne JC and Howley PM: The state of the p53 and retinoblastoma genes in human cervical carcinoma cell lines. Proc Natl Acad Sci USA 88: 5523-5527, 1991.

16. Scheffner M, Werness BA, Huibregtse JM, Levine AJ and Howley PM: The E6 oncoprotein encoded by human papillomavirus types 16 and 18 promotes the degradation of $\mathrm{p} 53$. Cell 63: 1129-1136, 1990.

17. Hietanen S, Lain S, Krausz E, Blattner C and Lane DP: Activation of p53 in cervical carcinoma cells by small molecules. Proc Natl Acad Sci USA 97: 8501-8506, 2000.

18. Butz K, Shahabeddin L, Geisen C, Spitkovsky D, Ullmann A and Hoppe-Seyler F: Functional p53 protein in human papillomavirus-positive cancer cells. Oncogene 10: 927-936, 1995.

19. Butz K, Whitaker N, Denk C, Ullmann A, Geisen C and Hoppe-Seyler F: Induction of the p53-target gene GADD45 in HPV-positive cancer cells. Oncogene 18: 2381-2386, 1999.

20. Offer H, Wolkowicz R, Matas D, Blumenstein S, Livneh Z and Rotter V: Direct involvement of p53 in the base excision repair pathway of the DNA repair machinery. FEBS Lett 450: 197-204, 1999.

21. Prost S, Bellamy CO, Clarke AR, Wyllie AH and Harrison DJ: p53-independent DNA repair and cell cycle arrest in embryonic stem cells. FEBS Lett 425: 499-504, 1998.

22. Fichorova RN, Rheinwald JG and Anderson DJ: Generation of papillomavirus-immortalized cell lines from normal human ectocervical, endocervical, and vaginal epithelium that maintain expression of tissue-specific differentiation proteins. Biol Reprod 57: 847-855, 1997.

23. Pillsbury HC and Bright CC: Comparison of aliquot and complete sample procedure for the determination of nicotine in cigarette smoke. J Assoc Off Anal Chem 55: 636-638, 1972.

24. Moktar A, Ravoori S, Vadhanam MV, Gairola CG and Gupta RC: Cigarette smoke-induced DNA damage and repair detected by the comet assay in HPV-transformed cervical cells. Int J Oncol 35: 1297-1304, 2009.

25. De Marini DM: Genotoxicity of tobacco smoke and tobacco smoke condensate: a review. Mutat Res 567: 447-474, 2004.

26. Loft $S$ and Poulsen HE: Cancer risk and oxidative DNA damage in man. J Mol Med 74: 297-312, 1996.

27. Wilmer MJ, De Graaf-Hess A, Blom HJ, et al: Elevated oxidized glutathione in cystinotic proximal tubular epithelial cells. Biochem Biophys Res Commun 337: 610-614, 2005.

28. Wei L, Gravitt PE, Song H, Maldonado AM and Ozbun MA: Nitric oxide induces early viral transcription coincident with increased DNA damage and mutation rates in human papillomavirus-infected cells. Cancer Res 69: 4878-4884, 2009.

29. Shackelford RE, Kaufmann WK and Paules RS: Oxidative stress and cell cycle checkpoint function. Free Radic Biol Med 28: 1387-1404, 2000.

30. Liu X, Conner H, Kobayashi T, et al: Cigarette smoke extract induces DNA damage but not apoptosis in human bronchial epithelial cells. Am J Respir Cell Mol Biol 33: 121-129, 2005.

31. Kessis TD, Slebos RJ, Nelson WG, et al: Human papillomavirus 16 E6 expression disrupts the p53-mediated cellular response to DNA damage. Proc Natl Acad Sci USA 90: 3988-3992, 1993.

32. Crook T, Wrede D and Vousden KH: p53 point mutation in HPV negative human cervical carcinoma cell lines. Oncogene 6: 873-875, 1991.

33. Srivastava $\mathrm{S}$, Tong YA, Devadas $\mathrm{K}$, et al: The status of the $\mathrm{p} 53$ gene in human papilloma virus positive or negative cervical carcinoma cell lines. Carcinogenesis 13: 1273-1275, 1992. 
34. Zhou J, Ahn J, Wilson SH and Prives C: A role for p53 in base excision repair. EMBO J 20: 914-923, 2001.

35. Thaiparambil JT, Vadhanam MV, Srinivasan C, Gairola CG and Gupta RC: Time-dependent formation of 8-oxo-deoxyguanosine in the lungs of mice exposed to cigarette smoke. Chem Res Toxicol 20: 1737-1740, 2007.

36. Yang Q, Hergenhahn M, Weninger A and Bartsch H: Cigarette smoke induces direct DNA damage in the human B-lymphoid cell line Raji. Carcinogenesis 20: 1769-1775, 1999.

37. Dypbukt JM, Atzori L, Edman CC and Grafstrom RC: Thiol status and cytopathological effects of acrolein in normal and xeroderma pigmentosum skin fibroblasts. Carcinogenesis 14: 975-980, 1993.
38. Chakravarti D, Mailander PC, Cavalieri EL and Rogan EG: Evidence that error-prone DNA repair converts dibenzo[a,l]pyreneinduced depurinating lesions into mutations: formation, clonal proliferation and regression of initiated cells carrying H-ras onco-gene mutations in early preneoplasia. Mutat Res 456: $17-32,2000$. 